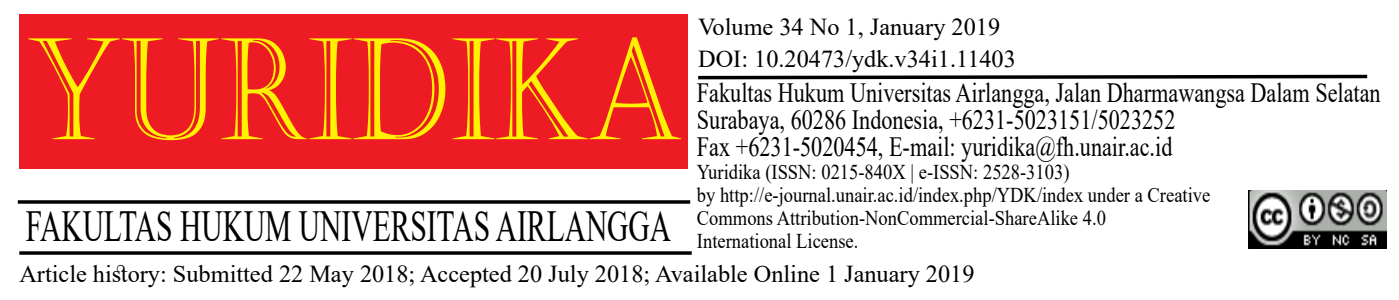

\title{
Dispute Settlement Mechanism In Bilateral Investment Treaties
} (BITs)

\author{
Yetty Komalasari Dewi and Arie Afriansyah \\ yettykomalasari@gmail.com \\ Universitas Indonesia
}

\begin{abstract}
The Bilateral Investment Treaty (BIT) or in Indonesia known as "Perjanjian Promosi dan Perlindungan Penanaman Modal (P4M)" contains a very powerful dispute settlement mechanism that allows investors to file a lawsuit directly against a host country allegedly violating investment protection under international law. This is known as Investor-State Dispute Settlement (ISDS). The ability of investors to "impose" their rights directly against a country without the existence of an arbitration clause is considered as one of the extraordinary achievements of the BIT innovation. This paper discusses two types of dispute resolution models contained in almost all BITs signed by Indonesia, namely State-State Dispute Settlement (SSDS) and Investor-State Dispute Settlement (ISDS). It also elaborates the weaknesses of the current dispute resolution formula, especially in the ISDS clause and provides the possibility of improvements to the formulation of the ISDS clause to better ensure a balance between the protection of foreign investors and the needs of the host country.
\end{abstract}

Keywords: BIT; IIA; Dispute Resolution; Investor-State; States.

\section{Introduction}

In various countries, Bilateral Investment Treaties (BITs) are not always the same, but most of them contain many commitments or promises to protect the investment and investors of a country (investors) in the territory of another 
country (host country). ${ }^{1}$ This protection includes treatment that is fair, equal and not discriminatory in overseeing the implementation of investment agreements and other obligations related to investment. The important thing is, in most cases, this kind of protection is accompanied by a very strong international arbitration mechanism that allows investors to file a lawsuit directly against a host country that is suspected of violating the protection under international law. The capability of investors to "enforce" their rights directly on a country without an arbitration agreement is considered as one of the extraordinary achievements of BIT innovation.

Just like other countries, BITs ${ }^{2}$ made by Indonesia was entered almost 50 years ago. ${ }^{3}$ The number of cases submitted through the Investor-State dispute settlement mechanism shows that there are shortcomings in the existing Bits' arrangement which only focus on protecting investors instead of ensuring the occurrence or presence of a balance with the development of the needs of the host country. ${ }^{4}$ In addition, BITs also contain obligations that are vague and too broad that has caused them to be the subject of a different decision in some cases of International Centre for Settlement of Investment Disputes (ICSID). To meet economic development in the 21 st century, countries that follow the old BITs model need to "modernize" the approach. By realizing the existence of

\footnotetext{
1 Investor of a country or other country's investor hereinafter is referred to as "investor", and the territory of another country hereinafter referred to as "host country"; or together is referred to as "investor-state".

2 This type of bilateral treaty also may be relevant to another field such as international trade see Esty Hayu Dewanti, 'Persyaratan Kandungan Lokal (Local Content Requirements) Di Indonesia Dan Kaitannya Dengan Perjanjian Internasional Di Bidang Investasi (Local Content Requirements in Indonesia and Its Relations with International Agreement on Investment)' (2012) 27 Yuridika $<$ https://e-journal.unair.ac.id/YDK/article/view/300>.[203-216].

3 The existence of BITs is expected to increase the flow of foreign direct investment. However, some scholars view differently. See Eric Neumayer and Laura Spess, 'Do Bilateral Investment Treaties Increase Foreign Direct Investment to Developing Countries?' (2005) 33 World Developmen.[1567-1585.]; Peter Egger and Michael Pfaffermayr, 'The Impact of Bilateral Investment Treaties on Foreign Direct Investment' (2004) 32 Journal of Comparative Economics.[788-804].; Jason Webb Yackee, 'Bilateral Investment Treaties, Credible Commitment, and the Rule of (International) Law: Do BITs Promote Foreign Direct Investment?' (2008) 42 Law \& Society Review.[805-832].

4 Martin Khor, 'A Note on The Investor-State Dispute Settlement (ISDS) System in The Context of BITS, South Center', The 7th Annual Forum of Developing Country Investment Negotiators, 4-6 December (Developing Country Investment Negotiators 2013).
} 
shortcomings in the existing BITs, ${ }^{5}$ many countries including Indonesia have reviewed the existence of its BITs and been trying to make improvements to its BITs so that in the future, BITs can better meet the objectives of improving the welfare of the nation in the context of sustainable development.

In general, BITs provide two dispute settlement mechanisms, namely the settlement of disputes between States that signed BITs (State-State Dispute Settlement) and settlement of disputes between Investors from BITs' Signatory Countries and other Countries where capital investment (Investor-Dispute Settlement) is carried out. The dispute settlement analysis in this paper focuses on the Investor-State dispute settlement mechanism.

\section{State-to-State Dispute Settlement}

Based on the results of a study of the 63 Indonesian BITs, InvestorState dispute settlement was not found in BIT with Canada, France and the United States. Dispute settlement with these three countries is in fact through the mechanism of State-State dispute settlement. The State-State dispute settlement provisions in BITs contain similar things, namely each dispute related to the interpretation or application of the provisions in the BITs or a claim that arises due to protected investment is settled diplomatically. However, there are slight differences in the formulation of the scope of disputes that can be resolved by the State-State mechanism listed in Canada and the United States' BITs with France's BIT. In BITs with Canada and the United States, the dispute covers disputes due to differences in interpretation or application of BITs and also disputes that occur due to investment. While France's BIT only covers disputes due to differences in interpretation or application of BIT.

5 Widhayani Dian Pawestri, 'Dialektika Perlindungan Kepentingan Nasional Berdasarkan Konstitusi Ekonomi Dengan Basic Principle Dalam Bilateral Investment Treaties (Dialectics for the Protection of National Interest Based on Economic Constitution with the Basic Principle in Bilateral' (2016) 31 Yuridika <https://e-journal.unair.ac.id/YDK/article/view/1961>.[143-166]. 
Table 1 State-State Dispute Settlement Scope Formulation

\begin{tabular}{lll}
\hline \multicolumn{1}{c}{ Canada } & \multicolumn{1}{c}{ United States of America } & \multicolumn{1}{c}{ France } \\
\hline Article 6 & Article 8 & Article 6 \\
Disputes concerning & Disputes concerning & Differences between the two \\
the interpretation or & the interpretation or & Governments concerning \\
implementation and & implementation and & the interpretation of the \\
application of provisions of this & application of the present & provisions of this Agreement \\
Agreement or any claim arising & Agreement shall be settled, & shall be settled insofar \\
out of investments insured & by means of diplomatic & as possible, through \\
... by means of diplomatic & negotiations between the & negotiations between the \\
channels between the two & Governments of Contracting & two Governments. \\
Governments & Parties. & \\
\hline
\end{tabular}

All IndonesianBITscontaining State-State dispute settlementclauses stipulate that if within a certain period of time (different periods of time in Canada's BIT which is three months while in France's BIT is five months) no agreement is reached, then the dispute is submitted to the ad hoc arbitral tribunal consisting of three arbitrators. Furthermore, the clause also regulates the procedure for establishing an arbitral tribunal. The provisions or rules used to resolve disputes, submitted to the discretion of the established arbitral tribunal. All clauses for State-State dispute settlement in the Indonesian BITs determine that the arbitral tribunal's decision is binding.

\section{Investor-State Dispute Settlement}

International arbitration between investors and the host country in BIT usually takes place at ICSID, which is an affiliate of the World Bank. ICSID specifically handles arbitration and conciliation for investment disputes based on the Convention on Settlement of Investment Disputes between States and Nationals of Other States which was formed in Washington in 1965 (known as "the ICSID Convention"). However, ICSID is not the only institution for investors to file a lawsuit against the host country according to BIT because some BITs provide other options to investors, including ad hoc arbitration or arbitration based on the International Chambers of Commerce (ICC). Until now, as long as arbitration through ICSID is possible, investors usually prefer ICSID because the provision 
to implement an arbitral award according to the ICSID Convention is better than the implementation of arbitral awards according to the ICC and other international arbitrations. However, recently, investors began to see other arbitration institutions that gave the option to review arbitral awards and generally had a more confidential process. Some recent studies conducted by the United Nations Conference on Trade and Development (UNCTAD) state that almost one third (1/3) of arbitration are not carried out by ICSID. ${ }^{6}$

The ICSID decision can be executed as a domestic verdict of a country from a signatory country to the ICSID Convention. The ICSID Convention does not allow domestic courts for any reason to object or make legal remedies or appeal against the ICSID decision, although it is still possible to make repairs, changes or cancellations of ICSID decisions internally for certain reasons. Only ICSID decisions can be made in the host country according to the ICSID Convention, while other international arbitral awards, including the ICC, are executed or carried out based on the United Nations Convention on Recognition and Enforcement of the Foreign Arbitral Awards signed on June 10, 1958, and known as "New York Convention". According to this Convention, domestic/local courts can only reject the execution of arbitral awards for certain reasons. In addition, ICSID is the only international arbitration institution that publishes registration or registration of arbitration claims against a country.

Based on the review of the 63 BITs signed by Indonesia with Partner Countries, Investor-State Dispute Settlement (ISDS) clauses can be divided into five (5) major groups, as follows: ${ }^{7}$

${ }^{6}$ UNCTAD, 'United Nations Conference on Trade and Development, Recent Developments in Investor-State Dispute Settlement (ISDS), International Investment Agreements Issues Note, No. 1, May 2013.', United Nations Conference on Trade and Development, Scope and Definition (United Nations 2013).

${ }^{7}$ Complete elaboration can be seen in the Dispute Settlement Clause Matrix. The analysis is only carried out on the Investor-State dispute settlement clause and does not cover the StateState dispute settlement clause. This is because, among other things, not many investment disputes submitted through the State-State mechanism. 
Table 2 Category of ISDS Dispute Settlement Clause

\begin{tabular}{|c|c|c|c|c|}
\hline I & II & III & IV & V \\
\hline $\begin{array}{l}\text { Algeria, } \\
\text { Argentina, Australia, } \\
\text { Bangladesh, Bulgaria, } \\
\text { Chile, China, Croatia, } \\
\text { Cuba, Czechoslovakia, } \\
\text { Denmark (2007), Egypt, } \\
\text { Finland, Germany, } \\
\text { Guyana, Hungary, India, } \\
\text { Iran, Jordan, North Korea, } \\
\text { Republic of Korea, } \\
\text { Kyrgyz, Laos, Libya, } \\
\text { Mauritius, Mongolia, } \\
\text { Morocco, Netherlands } \\
\text { (1994), Norway (1991), } \\
\text { Pakistan, The Philippines, } \\
\text { Poland, Qatar, Romania, } \\
\text { Russia, Saudi Arabia, } \\
\text { Singapore, Slovakia, Sri } \\
\text { Lanka, Sudan, Suriname, } \\
\text { Syria, Tajikistan, } \\
\text { Thailand, Tunisia, Turkey, } \\
\text { Ukraine, Uzbekistan, } \\
\text { Vietnam, Yemen, } \\
\text { Zimbabwe, Serbia, } \\
\text { Mozambique [54] }\end{array}$ & $\begin{array}{l}\text { Canada, Denmark } \\
\text { (1968), France, } \\
\text { Netherlands } \\
\text { (1968), Norway } \\
(1969), \\
\text { Switzerland } \\
\text { Confederation, } \\
\text { Turkmenistan, } \\
\text { United States of } \\
\text { America [5] }\end{array}$ & Belgium [1] & $\begin{array}{l}\text { Cambodia, } \\
\text { Malaysia, } \\
\text { Sweden [3] }\end{array}$ & $\begin{array}{l}\text { Great } \\
\text { Britain and } \\
\text { Northern } \\
\text { Island [1] }\end{array}$ \\
\hline
\end{tabular}

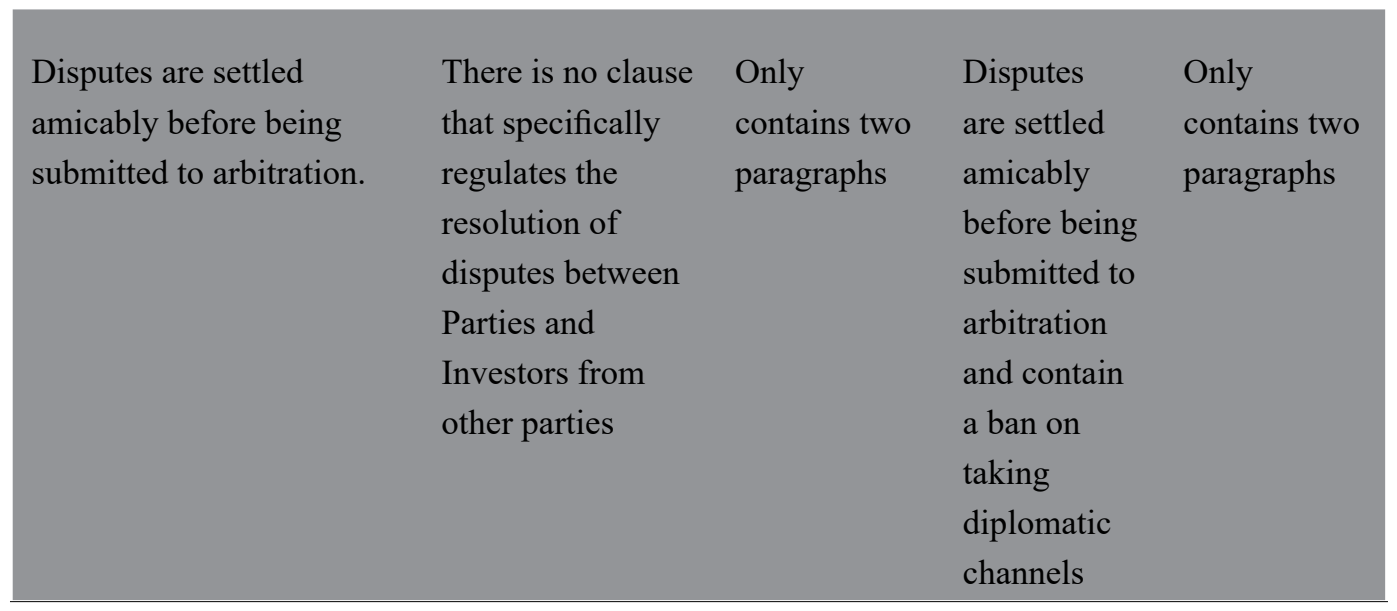

Analysis of the 63 BITs between Indonesia and Partner Countries includes the following. 


\section{Scope and Coverage of Investor-State Dispute Settlement}

The first clause in the Investor-State dispute settlement provisions generally describes the type of dispute that can be resolved by implementing the mechanism. Most Indonesian BITs contain a wide scope. Some BITs implement Investor-State dispute settlement mechanism with the obligation to amicably negotiate all disputes arise between investors and the host country.

Some Indonesian BITs still follow a traditional or conventional approach, namely by determining the scope of Investor-State dispute settlement including any investment-related disputes between Investors and Indonesia (as the host country). Some words that are usually used are "related to", "concerned with", "connected to", "arising out of" investment and the like. This wording formulation is seen in several Indonesian BITs, including BITs with China, Singapore, and Australia, below.

"Article 9

1. Any dispute between an investor of one Contracting Party and the other Contracting Party in connection with an investment in the territory of the other Contracting Party ... [China].

Article 8

1. Any dispute between a Contracting Party and an investor of the other Contracting Party concerning investment of the latter in the territory of the former...[ Singapore]

\section{Article 11}

In the event of a dispute between a Party and an investor of the other Party relating to an investment,... [Australia]

\section{Article 10}

Any dispute which arises within the terms of this Agreement concerning an investment between investors... [Argentina]

\section{Article 9.}

Any dispute between an investor of one Contracting Party and the other Contracting Party concerning an investment. [the Netherlands]".

The formulation above opens the opportunity to file arbitration against disputes that are not related to the substantive protection of BIT, for example, disputes arising from domestic law, customary international law or investment agreements. This 
approach is usually complemented by applicable law clause, namely in addition to the provisions in BIT and international law, also domestic/local laws from the Host Country. This is more appropriate for BIT which has a broad scope of InvestorState dispute settlement. In the formulation below, the Arbitral Tribunal may provide decisions related to matters not only originating from BIT but also from domestic/local laws, including for instance investment agreements: "The tribunal shall adjudicate in accordance with the laws of the Contracting Party to the dispute, the provisions of this Agreement as well as generally recognized principle of international law accepted by both Contracting Parties. [Indonesia-China]".

Such formulation of the scope above results in jurisdictions that are too broad and not precisely defined so that the results will depend on the interpretation made by the Arbitral Tribunal in a dispute. In addition, the formulation increases the potential of State responsibility internationally. In practice, most of the disputes submitted are based on the type or type of clause, until today related to alleged violations of BIT and not other legal provisions.

Indonesia recently received a lawsuit at the ICSID using the scope clause. This is a dispute between Indonesia and one of Century Bank's shareholders, Rivzi, who filed a lawsuit to the ICSID on the basis of BIT between Indonesia and the United Kingdom. Article 2 of BIT between Indonesia and the United Kingdom states:

"This Agreement shall only apply to investments by nationals or companies of the United Kingdom in the territory of the Republic of Indonesia which have been granted admission in accordance with the Foreign Capital Investment Law No. 1 of 1967 or any law amending or replacing it.“

According to the case of Indonesia v. Rizvi, although in the end the arbitral tribunal accepted the Exception carried out by the Indonesian government, it should be observed closely the opinion of the panel of judges that the words "in accordance with the Foreign Capital Investment Law No. 1 of 1967 or any law amending or replacing it", it must be interpreted that investments protected by the BIT between Indonesia and the United Kingdom are not only carried out through The Investment Coordinating Board of the Republic of Indonesia or Badan Koordinasi Penanaman 
Modal (BKPM) but also investments made in other sectors which are not regulated by BKPM, insofar as they do not conflict with the law applicable in Indonesia. ${ }^{8}$

Therefore, to emphasize that only foreign direct investment through BKPM is protected by BIT which can be resolved through the Investor-State dispute settlement mechanism (ICSID), the words "in accordance with ..." should be changed with the word "by BKPM". ${ }^{9}$ So that the proposed change in the clause that regulates the scope and coverage of BIT becomes "This Agreement shall only apply to investments by nationals or companies of the United Kingdom in the territory of the Republic of Indonesia which have been granted admission by BKPM”.

\section{State's Consent to Arbitration}

One of the important things in Investor-State dispute settlement clause is consent by the Host Country to pursue an international arbitration process or mechanism on the investment disputes. In several BITs signed by Indonesia, it was clear that Indonesia consented to the Investor-State dispute settlement mechanism since the beginning as shown below.

"Article 9

Each Contracting party hereby consents to submit any legal dispute arising between that Contracting Party and a national of the other Contracting Party concerning an investment of that national in the territory of the former Contracting Party to the International Centre for Settlement of Investment Disputes for settlement by conciliation or arbitration under the Convention on the Settlement of Investment Disputes between States and Nationals of other States opened for signatures at Washington on 18 March 1965 [The Netherland]. ${ }^{10}$

\footnotetext{
8 One arbitrator, Sornarajah disagreed and stated “...it is difficult to see how the purchasers of shares in banks on the open stock exchange or from other shareholders can come to be protected by the treaty... such private transactions are incapable of creating responsibility of the state." $\square$ that a country cannot be held liable for every private transaction in the capital market. [para 4 Separate Concurring Opinion ICSID Case No. ARB/11/13: Rizvi v. RI].

9 Results of the Balikpapan FGD on the Review of Indonesian BIT, September 30, 2013, delivered by Iswahjudi Karim. The FGD was hosted by the Indonesian Coordinating Board of Investment (BKPM).

${ }^{10}$ On the BIT between Indonesia and the Netherlands made in 1968, there is no clause regarding dispute settlement between a foreign investor and the host country.
} 
Article 10

Each Contracting Party hereby irrevocably and anticipatory gives its consent to submit to conciliation and arbitration any dispute relating to measuring contrary to this Agreement, pursuant to the Convention of Washington of 18 March 1965, at the initiative of national or legal person of the other Contracting Party, who considers himself to have been affected by such a measure. [Belgium].

\section{Article 7}

In the event that such a dispute cannot be settled amicably within six (6) months from the date of the written notification of such dispute, the investor may refer the dispute to either:

a. The courts of justice or administrative tribunals or agencies of competent jurisdiction of the Contracting Party that is a party to the dispute; or

b. The International Centre for Settlement of Investment Disputes (hereinafter referred to as "the Centre"). [Malaysia]".

The consequence of Indonesia giving consent to pursue the InvestorState dispute settlement mechanism is that the agreement cannot be withdrawn unilaterally. In this case, the Host Country cannot hinder or prevent investors from filing lawsuits related to BIT against the Host Country. Indeed, this formulation provides more certainty to investors and makes the Investor-State dispute settlement mechanism to be effective, so as to strengthen the "promotion" function of a BIT.

Whereas in BIT between Indonesia and Malaysia, it appears that the formulation of consent by Indonesia is not expressed explicitly but can be interpreted from the words in the BIT. If observed, the provision does not explicitly state the agreement of the Parties to take the arbitration mechanism when in disputes. Consent is fulfilled if BIT allows foreign investors to submit a dispute to arbitration.

\section{Amicable Settlement \& Alternative Dispute Settlement}

"Article 8

1. Any dispute between a Contracting Party and an investor of the other Contracting Party, concerning investment of the latter in the territory of the former, shall be settled amicably through consultations and negotiations. [The Philippines]".

The BIT between Indonesia and the Philippines above contains provisions for conducting consultations and negotiations between the Parties to the dispute before 
the arbitration dispute settlement process or mechanism is taken. Based on the formulation of the above provisions, the BIT requires Indonesia and investors from the Philippines to take a method of consultation and negotiation first in an effort to resolve the dispute amicably. The condition for achieving maximum results from this process is active participation and good faith from the parties to the dispute. However, it must be understood that not all disputes can or are suitable to be resolved by means of a mediation or conciliation process. Most dispute settlement clauses use the format that dispute settlement starts with a non-confrontation settlement process, namely by negotiation and consultation. Then if the time has run out and a settlement of the investment dispute has not yet to be achieved, the foreign investor can bring the investment dispute to another forum specified in the BIT.

\section{Conditions precedent to Arbitration}

"Article 8

...Where an investor has submitted a dispute to the aforementioned competent tribunal of the Contracting Party where the investment has been made or to international arbitration, the choice shall be final. [Argentina].

\section{Article 9}

If the dispute cannot thus be settled within a period of six months from the date on which the dispute has been raised by either Party, it may be submitted upon request of the investor (his choice will be final) either to... [Egypt].

Article 9

Submission of a dispute to domestic judicial procedures under paragraph 2 above shall not in any way affect the right of the nations concerned to submit the dispute to international arbitration or conciliation. [The Netherlands]".

If observed, there are differences between those three clauses above. The clause on BIT between Indonesia and Argentina and Egypt illustrates the obligation of Investors to choose between domestic and international arbitration. However, once the Investor initiates the proceedings at the domestic trial, he loses his right to take or file a lawsuit before arbitration, and vice versa. The purpose of this clause is to prevent multiple proceedings arising from the same legal 
facts or parallel proceedings. ${ }^{11}$ If this happens, it will bring losses, especially for Indonesia because it will cost a lot of time and money. This approach is sometimes referred to as the "no U-turn" clause because although according to the clause the investor can take other legal remedies within a certain time, the clause only allows the plaintiff to go one way to Investor-State arbitration. This "no U-turn" clause should not be misunderstood by requiring investors to exhaust local remedies before submitting the dispute to arbitration. However, it should also be noted that the formulation above reduces the interest of investors to use domestic/local justice.

While the third formula, namely in BIT with the Netherlands, is the opposite. The formula allows investors to, together, submit the same claim to two different forums, namely one taking the domestic/local court while the other taking the international arbitration mechanism. In some BITs, the State also requires that investors first take the domestic/local justice process to completion before they are entitled to the right to submit a dispute to international arbitration. This is known as "exhausted local remedies" as mentioned above. However, Indonesian BIT has no clause of this kind. Even the BIT between Indonesia and Belgium actually gives the parties the right to submit actions that are considered to violate the BIT to the ICSID without the need to complete all stages or administrative/domestic/local legal processes.

"Article 10

1. Each Contracting Party hereby irrevocably and anticipatory gives its consent to submit to conciliation and arbitration any dispute relating to measuring contrary to this Agreement, pursuant to the Convention of Washington of 18 March 1965, at the initiative of national or legal person of the other Contracting Party, who considers himself to have been affected by such a measure.

2. This consent implies renunciation of the requirement that the internal administrative or judicial resorts should be exhausted. [Belgium]".

At the present time, more and more BITs contain clauses that require the use of

\footnotetext{
${ }^{11}$ Trials in the case of the same lawsuit and the same parties that are submitted in two or more different forums can have different decisions.
} 
domestic/local legal measures to be completed before Investors submit a lawsuit to arbitration. Such clauses indeed, on one hand, encourage the use of domestic/local legal processes. However, on the other hand, although it depends on each country, it takes a long time before the Investor gets a decision and immediately takes the arbitration process. This will reduce the "attractiveness" of BITs for investors. As a middle ground, the use of domestic/local legal processes is still required in BITs and does not have to be completed for all of the stages but it is sufficient to set a period of time. ${ }^{12}$ As already mentioned, that in the dispute settlement formulation in BITs signed by Indonesia there is no obligation for foreign investors to go to the domestic courts until completion (exhaustion of local remedies) therefore foreign investors are not obliged to resolve disputes through the domestic court; hence they can promptly submit any dispute to international arbitration.

\section{Arbitration Rules}

"Article 10

(3) In the case of international arbitration, the dispute shall be submitted at the investor's choice, either to:

a. The International Centre for the Settlement of Investment Disputes (ICSID) ...; or

b. An Arbitration Tribunal set up from the case to case in accordance with the arbitration rules of the United Nations Commission on International Tread Law (UNCITRAL);

c. The Arbitration Tribunal shall decide in accordance with the provisions of this Agreement, the laws of the Contracting Party involved in the dispute, including its rules on conflicting of law, the terms of any specific agreement concluded in relations to such an investment and relevant principles of international law. [Argentina]".

The clause states that investors decide on which international arbitration dispute settlement institutions to be used. It must be understood that arbitrators are appointed by the Authorized Parties to obtain decisions on each particular case. ICSID is an independent institution, in a supranational system, protected

\footnotetext{
${ }^{12}$ Based on the results of interviews with Prof. Loukas Mistelis, Queen Mary University of London [London], Mr. Audley Sheppard, Clifford Chance Law Firm [London], representative of the International Investment for Sustainable Development [Geneva].
} 
from domestic/local justice and protected from the influence of national/legal law regarding arbitration. Domestic/local justice does not have the authority to revise, cancel or override the decisions given in the ICSID Convention.

The second arbitration rule that is often chosen by the parties, including Indonesia in regards to BIT is UNCITRAL Arbitration Rules. The place or country (legal seat) that will be used to resolve the dispute is chosen by the parties. The arbitral award is executed through a domestic/local court, usually in accordance with the New York Convention. However, based on this Convention also, the State has the right to refuse to implement an arbitral award if it meets the criteria for it. For an example, if it turns out the arbitration decision is contrary to the public interest of the State. In addition, UNCITRAL Arbitration Rules are often used because they have a high level of confidentiality. Disputes that occur can be kept confidential if the parties want it so. Of course, BIT can change the nature of this secrecy to increase transparency in the procedure.

All BITs signed by Indonesia which contain UNCITRAL Arbitration Rules are very standard, which only mentions the choice of arbitration rules. Besides being seen in the BIT between Indonesia and Argentina above, this is also evident in the following BIT between Indonesia and Egypt.

"Article 9

1. Any dispute which may arise between a Contracting Party and an investor of the other Contracting Party, if possible, shall be settled amicably.

2. If the dispute cannot thus be settled within a period of six months from the date on which the dispute has been raised by either Party, it may be submitted upon request of the investor (his choice will be final) either to:

a. The competent court of the Contracting Party in whose territory the investment was made;

b. The ICSID...;

c. Regional Center for International Commercial Arbitration in Cairo as far as it applies UNCITRAL".

One of the important issues that come to developing countries' attention and various parties related to international arbitration decisions is the issue of disclosure (transparency), specifically referring to decisions made by the ICSID arbitral tribunal. Until now, ICSID itself has not taken steps to review its rules to be more 
transparent. However, this step has been carried out by UNCITRAL which currently has provisions regarding transparency. ${ }^{13}$

\section{Presentation of Claim}

In each BIT, the State determines on whose behalf a claim can be submitted. Most Indonesian BITs determine that Investors can file a claim to arbitration in their own name. The formulation can be seen in some BITs below as follows.

"Article 11

In the event that such a dispute cannot be settled through consultations and negotiations, the investors in question may submit the dispute, for settlement: [Australia]

\section{Article 10}

1. In the case of international arbitration, the dispute shall be submitted at the investor's choice, either to: [Argentina]

Article 10

Each Contracting Party hereby irrevocably and anticipatory gives its consent to submit to conciliation and arbitration any dispute relating to measuring contrary to this Agreement, pursuant to the Convention of Washington of 18 March 1965, at the initiative of national or legal person of the other Contracting Party, who considers himself to have been affected by such a measure [Belgium]

\section{Article 7}

The Contracting Party in the territory of which a national or company of the other Contracting Party makes or intends to make an investment shall assent to any request on the part of such national or company to submit... [The United Kingdom]".

This formulation is a formula commonly used in investment agreements and is a standard formula (default position). Most of the BITs only refer to any dispute between the Investor and the Host Country in connection with investment and does not expressly state on whose behalf the Investor can file a claim. Therefore, the

${ }^{13}$ UNCITRAL, 'UNCITRAL Rules on Transparency in Treaty-Based Investor-State Arbitration' (UNCITRAL provision regarding transparency is valid since 1 April 2014, 2014) <http://www. uncitral.org/uncitral/en/uncitral_texts/arbitration/2014Transparency.htm> accessed 24 May 2017. 
Investor can only file a claim in his own name unless the provisions in BIT also give him the authority to file a claim on behalf of a local company that he owns or controls. In BIT with Belgium, it is distinguished between "national" which refers to people (natural individuals) and "legal person" that refer to legal subjects with legal status (legal entity); whereas in BIT with the United Kingdom, the formula used is "national" or natural person and "company" which refers to legal entities.

Considering the development of legal cases related to investment disputes submitted to ICSID on the basis of BIT, it should also be considered in the case of Investors who are shareholders (majority or minority) of Indonesian legal entities filing claims, the compensation claims requested by them must be adjusted with the amount of the share ownership as well as the actual loss. Besides that, it needs to be considered carefully when it comes to formulating investments made through the establishment of companies in the Host Country, which in Indonesia are often carried out by forming joint venture companies as required by Law No. 25/2007 concerning Investment. If an Investor is a shareholder of an Indonesian legal entity, the claim can be stated on the basis of, for example, the expropriation of his shares or the refusal of his right to obtain dividends. Therefore, to avoid a lawsuit based on these reasons, it is best to exclude these reasons or be excluded from the scope of the Investor-State dispute settlement.

\section{Establishment of the Arbitration Tribunal}

Based on the results of a study of the 63 BITs that Indonesia signed with Partner Countries, most of them did not contain the clause for the formation of the arbitral tribunal. As stated earlier, the 63 BITs have been categorized based on the type of dispute settlement "clause", and are divided into five major groups. Based on the grouping, most of the BITs only submit to the arbitration institution mentioned in BIT whether it refers to ICSID or UNCITRAL. This can be seen from BIT with the Netherlands (group 2) which does not contain the Investor-State dispute settlement clause especially the arbitration tribunal's clause. Furthermore BIT with Belgium (group 3), Malaysia and Sweden (group 4), and England (group 5). 
This is different in BIT with China which includes a clause concerning the formation of an arbitral tribunal, as follows.

"Article 9

3. The ad hoc tribunal shall be constituted for each individual case in the following way: each party shall appoint an arbitrator, and these two shall select a national of a third state which has diplomatic relations with the two Contracting Parties as Chairman, the first two arbitrators shall be appointed within two months of the written notice for arbitration by either party to the other, and the Chairman be selected within four months. If within the period specified above, the tribunal has not been constituted; either party to the dispute may invite the Secretary-General of the International Center for Settlement of Investment Disputes to make the necessary appointments.

The tribunal shall determine its own procedure. However, the tribunal may, in the course of determination of procedure, take as guidance the Arbitration Rules of the International Center for Settlement of Investment Disputes... [China]".

If in BITs there are no rules regarding the appointment of arbitrators, the arbitrators will be appointed by referring to the procedure contained in the arbitration rules. The way to appoint the arbitrators differs between ICSID rules and UNCITRAL rules. According to ICSID, the parties to the dispute appoint one arbitrator each and then they (the parties) jointly appoint one more arbitrator as chairman; whereas according to UNCITRAL, the parties to the dispute appoint one arbitrator each and the two arbitrators appointed are those who will appoint one more arbitrator as the leader of the arbitrator.

In addition, all Indonesian BITs do not contain clauses regarding arbitrator qualifications and rules regarding fees or remuneration for arbitrators. Even though this needs to be considered to limit the risk of the Host Country especially in terms of costs that must be paid to the arbitrators. This issue is one of the concerns of developing countries in the $7^{\text {th }}$ Annual Forum of Developing Country Investment Negotiators held in Jakarta on 4-6 November 2013.

\section{Consolidated-claim}

The consolidation clause was first included in the 2004 United States BIT Model which aims to avoid multiple lawsuits simultaneously (parallel), encourage 
faster and more affordable costs of decisions on consolidation claims, and avoid inconsistent results in several claims originating from the same actions or measures. ${ }^{14}$

Given that most of the BITs signed by Indonesia were carried out almost a decade ago and even more, the clause of the consolidation lawsuit was not found in all of the BITs. Consolidation is the act of combining or merging and completing in one arbitral tribunal several disputes or claims submitted separately but actually still related. This will result in a more efficient arbitration ruling and can help prevent the potential for different and even conflicting decisions from some of the claims originating from the same measure. Indeed, most BITs, not only Indonesia, do not contain this kind of clause.

In addition to the consolidation lawsuit, the Indonesian BITs have not yet included a clause on a "frivolous claim" as well as an attempt or retaliatory action from the Host Country, namely a counter-claim. For example, Columbia in its BIT has included this clause which states that if an investment company is proven to have committed corruption, it has no right to sue the government or it can sue, but the number of damages proposed must be reduced. ${ }^{15}$

\section{Remedies}

Based on the results of the reviews on the 63 Indonesian BITs, no provision of remedies is found in dispute settlement clauses. The approach that does not include the provisions of remedies effort is indeed an approach that is mostly carried out in most BITs. However, the absence of such a clause will give substantial discretion to the arbitral tribunal to determine what remedies will be given in the arbitral award according to their opinion.

In general, efforts to remedies in the process of Investor-State dispute settlement can be in the form of financial (pecuniary) and non-financial (non-

\footnotetext{
${ }^{14}$ Henri C. Alvarez, 'Arbitration under the North American Free Trade Agrement' (2016) 16 Arbitration International 393.[413-414].

${ }^{15}$ The $7^{\text {th }}$ Annual Forum of Developing Country Investment Negotiators, Jakarta 4-6 November 2013 .
} 
pecuniary). Non-financial remedies are usually in the form of asset recovery, meaning that the arbitral tribunal orders the respondent to return certain assets to the claimant, for example in the case of expropriation. In addition, it can also take the form of an order to revoke, cancel or change provisions or actions that have legislative, administrative or even legal product or rules.

\section{Finality and Enforcement of Arbitral Awards}

As well as several clauses that have not been found in Indonesian BITs, clauses about finality and enforcement of arbitral awards are also not found in those 63 Indonesian BITs. However, some BITs contain clauses that reaffirm that the arbitral award binds the parties and requires the State to ensure its implementation (execution). This means that provisions/laws must be established and the local institution will implement the international arbitral award, and the Host Country may not prevent the execution of the decision. In addition, the implementation of the arbitral award itself is governed by the provisions of the ICSID stating that the arbitral award must be treated as a final decision from the domestic/national court. The same thing is also regulated in UNCITRAL rules.

In Indonesia, since the enactment of Law No. 30 of 1999 concerning Arbitration and Alternative Disputes Settlement, the question of whether foreign or international arbitral awards can be implemented in Indonesia has been answered. According to the Law, foreign or international arbitration decisions can be executed in Indonesia by first requesting a determination from the Central Jakarta District Court. ${ }^{16}$

\section{Conclusion}

In general, for the interests of Indonesia, which becomes one of the objectives of foreign investment, the dispute settlement clause between foreign investors

\footnotetext{
${ }^{16}$ See Article 67, Law No. 30 of 1999 on Arbitration.
} 
and the host country is not an advantage because this clause is the result of the effort of the exporting country of foreign investors to protect investors from their country. ${ }^{17}$ On the other hand, with the existence of the clause, the Host Country allows foreign Investors to directly file a claim to international arbitration in the event of investment disputes. ${ }^{18}$

According to Mahnaz Malik, the Host Country has little chance to "win" in a lawsuit brought to international arbitration. Winning in international arbitration, according to him, is when the investor's claim is rejected by the arbitral tribunal so that the Host Country does not need to pay compensation to the Investors. But the Host Country still has to pay court fees in the international arbitration process using the Host Country's money. ${ }^{19}$

The absence of Investor-State dispute settlement clause means that there is no direct agreement between the host country and foreign investors to submit disputes to international arbitration. ${ }^{20}$ With no agreement from the host country, foreign investors cannot bring the host country to international arbitration using BIT. ${ }^{21}$

The development of BITs over the past few decades shows the trend of the review of the existence of BITs in almost all developing countries. Given that almost all BITs were signed around four or five decades ago, the notion that the

\footnotetext{
${ }^{17}$ Jan Ole Voss, Impact of Investment Treaties on Contracts between Host States and Foreign Investors (Martinus Nijhoff Publisher 2011).[50].

18 ibid.[81-87].

19 Mahnaz Malik, 'The Stakes of States in Defending Investment Treaty Arbitrations: A Game of Luck and Chance?', IV Annual Forum for Developing Country Investment Negotiators, International Institute for Sustainable Development (IISD) $i$ (IISD 2010).[1-3].

20 ibid.[57].

${ }^{21}$ Article 25 (1) ICSID Convention states:

The jurisdiction of the Centre shall extend to any legal dispute arising directly out of an investment, between a Contracting State (or any constituent subdivision or agency of a Contracting State designated to the Centre by that State) and a national of another Contracting State, which the parties to the dispute consent in writing to submit to the Centre. When the parties have given their consent, no party may withdraw its consent unilaterally.

Or in Article 1 (1) of the UNCITRAL Rules of Arbitration:

Where parties have agreed that disputes between them in respect of a defined legal relationship, whether contractual or not, shall be referred to arbitration under the UNCITRAL Arbitration Rules, then such disputes shall be settled in accordance with these Rules subject to such modification as the parties may agree.
} 
clauses contained in BIT focus more on protection for investors, and the absence of clauses designed to ensure economic growth and development in the Host Country, is true. ${ }^{22}$ Therefore, at present the main need in conducting BIT reviews by various countries, including Indonesia, is on one hand, ensuring that BITs to be made in the future, if deemed necessary, should provide greater clarity between the standards of protection for investors that have existed, and on the other hand, dismissing that the development goals can or should be realized in BIT clauses in the future, especially in the Investor-State dispute settlement mechanism clause.

\section{Bibliography}

Eric Neumayer and Laura Spess, 'Do Bilateral Investment Treaties Increase Foreign Direct Investment to Developing Countries?' (2005) 33 World Developmen.

Esty Hayu Dewanti, 'Persyaratan Kandungan Lokal (Local Content Requirements) Di Indonesia Dan Kaitannya Dengan Perjanjian Internasional Di Bidang Investasi (Local Content Requirements in Indonesia and Its Relations with International Agreement on Investment)' (2012) 27 Yuridika <https://ejournal.unair.ac.id/YDK/article/view/300>.

Henri C. Alvarez, 'Arbitration under the North American Free Trade Agrement' (2016) 16 Arbitration International 393.

Jan Ole Voss, Impact of Investment Treaties on Contracts between Host States and Foreign Investors (Martinus Nijhoff Publisher 2011).

Jason Webb Yackee, 'Bilateral Investment Treaties, Credible Commitment, and the Rule of (International) Law: Do BITs Promote Foreign Direct Investment?' (2008) 42 Law \& Society Review.

Mahnaz Malik, 'The Stakes of States in Defending Investment Treaty Arbitrations: A Game of Luck and Chance?', IV Annual Forum for Developing Country Investment Negotiators, International Institute for Sustainable Development (IISD) i (IISD 2010).

Martin Khor, 'A Note on The Investor-State Dispute Settlement (ISDS) System in The Context of BITS, South Center', The 7th Annual Forum of Developing

${ }^{22}$ It can be briefly stated that this assumption was also proven when the review of the 63 Indonesian BITs was conducted. 
Country Investment Negotiators, 4-6 December (Developing Country Investment Negotiators 2013).

Peter Egger and Michael Pfaffermayr, 'The Impact of Bilateral Investment Treaties on Foreign Direct Investment' (2004) 32 Journal of Comparative Economics.

UNCITRAL, 'UNCITRAL Rules on Transparency in Treaty-Based Investor-State Arbitration' (UNCITRAL provision regarding transparency is valid since 1 April 2014, 2014) <http://www.uncitral.org/uncitral/en/uncitral_texts/ arbitration/2014Transparency.htm> accessed 24 May 2017.

UNCTAD, 'United Nations Conference on Trade and Development, Recent Developments in Investor-State Dispute Settlement (ISDS), International Investment Agreements Issues Note, No. 1, May 2013.', United Nations Conference on Trade and Development, Scope and Definition (United Nations 2013).

Widhayani Dian Pawestri, 'Dialektika Perlindungan Kepentingan Nasional Berdasarkan Konstitusi Ekonomi Dengan Basic Principle Dalam Bilateral Investment Treaties (Dialectics for the Protection of National Interest Based on Economic Constitution with the Basic Principle in Bilateral' (2016) 31 Yuridika <https://e-journal.unair.ac.id/YDK/article/view/1961>

HOW TO CITE: Yetty Komalasari Dewi and Arie Afriansyah, 'Dispute Settlement Mechanism in Bilateral Investment Treaties (Bits)' (2019) 34 Yuridika. 